\title{
アルミニゥム陽極酸化皮膜の硫酸による電解発色法
}

\author{
高橋俊郎*・長野年宏* ・和田健二* ・鈴木康史 ${ }^{*}$ \\ ・田賀井秀夫**
}

\section{Integral Coloring of Anodic Oxide Films on Aluminum with Sulfuric Acid}

\author{
Fundamental Studies on Coloring of Alumina (Part 6)
}

\author{
Toshiro TAKAHASH, Toshihiro NAGANO, Kenji WADA, \\ Yasushi SUZUKI, Hideo TAGAI and Shushichi KIMURA
}

Anodic oxide films on aluminum were formed in $150 \mathrm{~g} / l \mathrm{H}_{2} \mathrm{SO}_{4}$ bath under particular electrolytic conditions of temperature, current density, and electric wave form. Then, integral coloring process of the films was investigated by means of electron probe X-ray microanalysis, fluorescent X-ray analysis, optical microscopy, decoloring processes accompanied with heat treatments, ultraviolet and visible absorption spectrum analysis, etc. The following results were obtained: (1) Self-colored films of anodic alumina could also be formed on aluminum in sulfuric acid. (2) The film, which had been anodized on 1100 aluminum by alternating current at $20^{\circ} \mathrm{C}$ for $40 \mathrm{~min}$., was found to contain iron on the boundary between aluminum and the film. (3) The colored films, which had been anodized by three kinds of electric wave forms: AC, DC-PR, and pulse-PR, were supposed to contain sulfur, which was analyzed to affect the self-color of the films. (4) In addition, the mechanism of integral coloring process of the films, which had been colored by electric wave forms such as DC and pulse, was supposed to be due to the defective crystal structure rather than effects of electron. (5) Colors of films were deepened by X-ray irradiation. Among the films, transparent alumina films were converted into light brown colored by X-ray irradiation.

\section{1. 緒 言}

アルミニウム陽極酸化皮膜 (以下, 皮膜之略す) の構 造とその発色機構については, 多くの研究が行なわれて いるにもかかわらず，いまだに未解決な点が多く存在し ている。そこで著者らは, 皮膜の発色機構の解明を目ざ し, 主として皮膜の結晶構造上の見地から研究を進めて きた。この結果皮膜の構造は一般的には欠陥スピネル型 の構造を有する $\gamma-\mathrm{Al}_{2} \mathrm{O}_{3}{ }^{1)}$ に類似の無定形アルミナを主 体とした構造であることを推察した。またこれまでに， 皮膜の発色法を分類してシュウ酸のような有機酸による

† アルミナの発色に関する基礎的研究 (第 6 報), 前報 （第 5 報）：金属表面技術，23，700（1972）

* 理研軽金属工業秼（静岡県静岡市曲金 $3-2-1$ ) Riken Light Metal Industrial Co., LTD.

** 科学技術庁無機材質研究所(茨城県新治郡桜村倉烓) National Institute for Researches in Inorganic Materials

*** 東京工業大学工業材料研究所 (東京都目黒区大岡山 2-12-1) Tokyo Institute of Technology
発色と, 硫酸で低温処理して得られる発色とを区別し, かつこれらの混酸による発色についても比較検討してき た。そして硫酸イオンやシュウ酸イオンのよらな陰イオ ンが，皮膜の発色に深い関連を持つことを報告した。そ こで発色原因をつきつめてみると, 有機酸の場合は従来 から言われているようにタール状物質のような高級炭化 水素2 と, 最近, 馬場引らによって提出された格子欠陷状 の空間にトラップされた不対電子あるいは有機のラジカ ルが主として発色に影響していると考兄られる。な拈, この他にもアルミニウム材料中の不純物元素4,5) による 効果孔考慮する必要がある。そして, 良好な発色皮膜を 得るためには, 必要に応じた電解条件の選択を計り, 上 記の発色因子のどれを優先させるかによって黄金色系か ら暗カッ色系に至るさまざまな色を得ることができる。 一方, 硫酸のよらな無機酸による発色は, 現段階では主と して黄色系と灰色系の色調が得られているにすぎず，こ の発色原因としてイオウ ${ }^{62}$ とアルミニウム材料中に含ま れる $\mathrm{Fe}$ のような不純物が考劣られている。以上のこと から, 硫酸とシュウ酸のよらな混酸を用いれば黄色系, 
カッ色系, 灰色系执よび黒色に至る明度, 彩度の異なっ た発色皮膜を容易かつ安定に得ることができるが，この ことは発色因子がすべてプラスされたことを考えれば， 良好な発色皮膜が得られるのも理解できる。しかし，本 研究では上記の事がらと今までに行なってきた一連の研 究結果とから, 硫酸のような無機酸単独液でも混酸によ る発色とほぼ類似の色調であるならば，生成が可能であ ろらとの発想のもとに研究を推進した。研究の実施にあ たり，発色をコントロールする条件として注目したのは 液温度, 電解波形および電流密度であった。この中でも
とくに重要なのは特殊な電解波形》),8)であって, これに よって酸化還元反応に上る発色と酸化反応のみによる発 色効果とを区分けし，それぞれの発色機構を追求した。 そして得られた皮膜に対して, 䫒微鏡で皮膜の断面色調 を観察後，偏光顕微鏡でその微細構造も観察した。そし て,さらに加熱による脱色試験, $\mathrm{X}$ 線マイクロアナライ ザーによる $\mathrm{Fe}, \mathrm{S}, \mathrm{O}$ 元素の分布扣よび蛍光 $\mathrm{X}$ 線によ るSK $\alpha$ 線のケミカルシフトから, 皮膜中の $\mathrm{SO}_{4}{ }^{2-}$ イオ ン, イオウ抽よ゙ $\mathrm{Fe}$ のような遷移金属と発色との関係 を追求した。またその電子構造については，紫外可視吸

表 1 種々の 電解波形と電解条件

\begin{tabular}{|c|c|c|c|c|c|c|c|}
\hline \multicolumn{2}{|c|}{ 電解波形 } & \multirow{2}{*}{$\frac{\begin{array}{c}\text { 電 解 温 度 } \\
\left({ }^{\circ} \mathrm{C}\right)\end{array}}{\begin{array}{c}5 \text { 以下 } \\
20\end{array}}$} & \multirow{2}{*}{$\begin{array}{c}\text { 電 解電圧 } \\
\text { (V) } \\
22 \sim 28 \\
17 \sim 20\end{array}$} & \multirow{2}{*}{$\begin{array}{c}\text { 皮膜 厚 } \\
(\mu) \\
(\mu) \\
33 \sim 75 \\
32 \sim 72\end{array}$} & $\begin{array}{l}\text { アルミニウ } \\
\text { ム 材 料 }\end{array}$ & \multirow{2}{*}{ 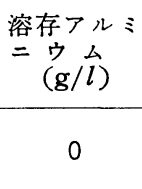 } & \multirow{2}{*}{$\begin{array}{l}\text { 表面色調 } \\
\text { 淡 死 色 } \\
\text { 無 }\end{array}$} \\
\hline \multirow{2}{*}{\multicolumn{2}{|c|}{$\mathrm{DC}$}} & & & & 1100 & & \\
\hline & & $\begin{array}{l}5 \text { 以下 } \\
20\end{array}$ & $\begin{array}{l}23 \sim 40 \\
17 \sim 25\end{array}$ & $\begin{array}{l}35 \sim 65 \\
30 \sim 67\end{array}$ & 1100 & 20 & $\begin{array}{l}\text { 扊 色 } \\
\text { 無 色 }\end{array}$ \\
\hline \multirow{5}{*}{$\mathrm{DC}-\mathrm{PR}$} & (1) & 5 以下 & $12 \sim 79$ & 56 & 1100 & 0 & 暗力ッ色 \\
\hline & \multirow{2}{*}{ (2) } & $\begin{array}{l}5 \text { 以下 } \\
20\end{array}$ & $\begin{array}{l}9 \sim 41 \\
7 \sim 28\end{array}$ & $\begin{array}{l}13 \sim 15 \\
11 \sim 22\end{array}$ & 1100 & 0 & 淡力ッ色 \\
\hline & & $\begin{array}{l}5 \text { 以下 } \\
20\end{array}$ & $\begin{array}{r}24 \sim 43 \\
9 \sim 44\end{array}$ & $\begin{array}{l}11 \sim 13 \\
12 \sim 13\end{array}$ & 1100 & 20 & 淡力ッ色 \\
\hline & \multirow{2}{*}{ (3) } & $\begin{array}{l}5 \text { 以下 } \\
10 \\
20 \\
\end{array}$ & $\begin{array}{l}12 \sim 80 \\
12 \sim 80 \\
17 \sim 37\end{array}$ & $\begin{array}{l}1 \sim 38 \\
1 \sim 56 \\
1 \sim 57\end{array}$ & 1100 & 0 & $\begin{array}{l}\text { 明 カッ色 } \\
\text { カ }{ }^{\circ} \text { 色 } \\
\text { 暗カッ色 }\end{array}$ \\
\hline & & $\begin{array}{l}5 \text { 以下 } \\
10 \\
20 \\
\end{array}$ & $\begin{array}{r}13 \sim 80 \\
16 \sim 85 \\
8 \sim 19 \\
\end{array}$ & $\begin{array}{r}1 \sim 18 \\
0.5 \sim 11 \\
1 \sim 27 \\
\end{array}$ & $99.99 \% \mathrm{Al}$ & 0 & $\begin{array}{l}\text { 淡カッ色 } \\
\text { 明カッ色 }\end{array}$ \\
\hline \multirow{4}{*}{ パ } & \multirow{4}{*}{ ス } & 5 以下 & $23 \sim 34$ & $53 \sim 88$ & $\frac{1100}{99.99 \% \mathrm{Al}}$ & \multirow{2}{*}{0} & \multirow{2}{*}{$\begin{array}{l}\text { 暗 カッ色 } \\
\text { 暗灭カッ色 } \\
\text { カ } ッ \text { 色 }\end{array}$} \\
\hline & & 20 & $17 \sim 28$ & $59 \sim 87$ & $\frac{1100}{99.99 \% \mathrm{Al}}$ & & \\
\hline & & 5 以下 & $18 \sim 34$ & $60 \sim 90$ & $\frac{1100}{99.99 \% \mathrm{Al}}$ & \multirow{2}{*}{20} & \multirow{2}{*}{$\begin{array}{l}\text { 暗 カッ色 } \\
\text { 暗灰カッ色 } \\
\text { カ } ッ \text { 色 }\end{array}$} \\
\hline & & 20 & $19 \sim 32$ & $60 \sim 87$ & $\frac{1100}{99.99 \% \mathrm{Al}}$ & & \\
\hline \multirow{2}{*}{\multicolumn{2}{|c|}{ パ ル スーP R }} & $\begin{array}{l}5 \text { 以下 } \\
20\end{array}$ & $\begin{array}{r}11 \sim 46 \\
9 \sim 27\end{array}$ & $\begin{array}{l}12 \\
12\end{array}$ & 1100 & 0 & 淡力ッ色 \\
\hline & & $\begin{array}{l}5 \text { 以下 } \\
20\end{array}$ & $\begin{array}{l}14 \sim 40 \\
10 \sim 30\end{array}$ & $\begin{array}{l}10 \\
12\end{array}$ & 1100 & 20 & 淡力ッ色 \\
\hline \multirow{3}{*}{$\mathrm{AC}$} & \multirow{2}{*}{ (1) } & $\begin{array}{l}5 \text { 以下 } \\
20\end{array}$ & $\begin{array}{l}13 \sim 27 \\
10 \sim 16\end{array}$ & $\begin{array}{l}2 \sim 7 \\
8 \sim 10\end{array}$ & 1100 & 0 & $\begin{array}{l}\text { 無 色 } \\
\text { 明 黄 }\end{array}$ \\
\hline & & $\begin{array}{l}5 \text { 以下 } \\
20\end{array}$ & $\begin{array}{r}10 \sim 21 \\
5 \sim 17\end{array}$ & $\begin{array}{l}2 \sim 6 \\
7 \sim 11\end{array}$ & 1100 & 20 & $\begin{array}{l}\text { 無 色 } \\
\text { 淡 黄 色 }\end{array}$ \\
\hline & (2) & 20 & $19 \sim 27$ & $\begin{array}{l}45 \\
42\end{array}$ & $\begin{array}{c}1100 \\
99.99 \% \mathrm{Al}\end{array}$ & 0 & 黄 \\
\hline
\end{tabular}

電解液組成: $\mathrm{H}_{2} \mathrm{SO}_{4} 150 \mathrm{~g} / l$, 電流密度 $: 2,4 \mathrm{~A} / \mathrm{dm}^{2}$, 電解槽 : $3 l$ ビーカー, 陰極 : カーボン, 極面積比 : 1 対 2 カクハン方法：空気, 使用した薬品：1 級 


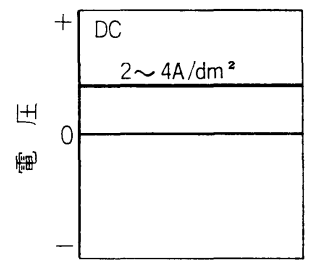

時 間 $\rightarrow$

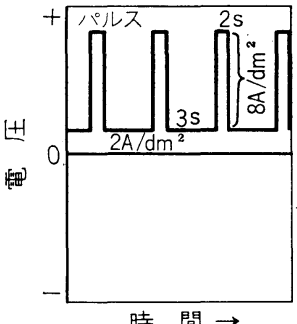

図 1 使用した電解波形
収スペクトルを測定したのでその結果も合わせて報告す る。

\section{2. 実験方法}

\section{2-1 供試材および皮膜の作成}

この研究に使用したアルミニウム材は, 試料寸法50X $100 \times 1 \mathrm{~mm}$ のもので1100Al 材（分析值：Fe $0.55 \%, \mathrm{Si}$ $0.14 \%, \mathrm{Cu} 0.03 \%$, Ti $0.02 \%, \mathrm{Mg}<0.01 \%, \mathrm{Mn}<0.01$ $\%$ ） c $99.99 \% \mathrm{Al}$ 板材（分析值：Fe $0.004 \%, \mathrm{Si} 0.0025$ $\%, \mathrm{Cu} 0.0025 \%, \mathrm{Ti}<0.01 \%, \mathrm{Mg}<0.01 \%, \mathrm{Mn}<0.01$ $\%$ の) 2 種類とした。前処理ははじめに $5 \% \mathrm{NaOH}, 60$ ${ }^{\circ} \mathrm{C}, 1 \mathrm{~min}$ の条件で脱脂処理後水洗し，続いて $10 \%$ $\mathrm{HNO}_{3}$, 室温, $20 \mathrm{~s}$ の条件で中和処理し, 最後に流水中 でよく水洗した。 $\mathrm{Al}$ の陽極酸化処理は, 図 1 と表 1 に 揭げたような電解波形と電解条件で行ない，原則として 定電流密度電解を行なった。そして皮膜は電解終了後よ く水洗したのち自然乾燥させた。なお,封孔処理は皮膜の 構造と色調に变化を执よぼすことから行なわなかった。

\section{2-2 皮膜の断面色調之微細構造の観察}

皮膜の断面色調観察はオリンパス工業秼製の POM 型 光学顕微鏡を使用した。そして，合成樹脂中に埋め込ま れ,かつ鏡面状に研摩された種々の発色皮膜断面を40倍, 100 倍でそれぞれ観察後カラー撮影した。また微細構造 を調ベるために使用した偏光顕微鏡は，オリンパス工業 (制製の PME 型万能顕微鏡で，100执よび400倍の倍率で 皮膜断面を観察後カラー撮影した。なおこのさいの撮影 条件は色温度 $4000^{\circ} \mathrm{K}$ または $4500^{\circ} \mathrm{K}$, Filter : LB 100 十 LB45, ASA：64，露出時間：3〜 5 min とした。

\section{2一3 加熱による脱色試験}

この試験は皮膜の厚サが薄いと加熱時にクラックが入 るだけでなく，皮膜の内部にある $\mathrm{Al}$ が溶解することに
よって割れてしまう忈れがある。したがって,この試験 に供した試料の皮膜厚サは約 $40 \mu$ 以上とした。加熱は20 ×10mm 角に切断した試料をアルミナ製のルッボに入 れ，ゴミが入らないよらにわずかにスキ間をあけた程度 にふたをして，空気らん囲気下の自動温度調節器付きの 電気炉中で行なった。加熱温度は $400^{\circ} \mathrm{Cから} 1100^{\circ} \mathrm{C}$ で $100^{\circ} \mathrm{C}$ 間隔で8段階に分けて行ない，それぞれの温度 での保持時間は30 min とした。な敃昇温速度は $1 \mathrm{~h}$ に約 $200^{\circ} \mathrm{C}$ であった。

2-4 EPMA による皮膜の断面における $\mathrm{Fe}, \mathrm{S}, \mathrm{O}$ の濃度分布測定

この測定は皮膜の脱色試験前後の試料を対象に行なっ た。EPMA 装置は島津製作所製の $\mathrm{EMX}-2 \mathrm{~A}$ 型を使用 し，皮膜断面中に含まれる $\mathrm{Fe} ， \mathrm{O}, \mathrm{S}$ のそれぞれ $\mathrm{K} \alpha$ 線 を測定し加速電圧 $25 \mathrm{kV}$, 試料電流 $0.05 \mu \mathrm{A}$, 電子線径約 $2 \mu \phi$, 試料走査スピード $8 \mu / 2 \mathrm{~cm} / \mathrm{min}$ とした。また

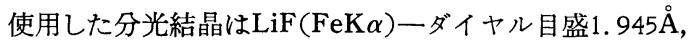

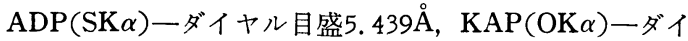

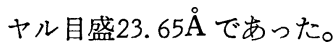

\section{2-5 蛍光 $\mathrm{X}$ 線による皮膜中の $\mathrm{SK} \alpha$ 線のケミカルシ フト}

硫酸皮膜中の S は電解波形がプラス成分（酸化反応） のみのときと，プラスとマイナス成分（酸化と還元 反 応）を交互にくり返したときとでは，その配位数に差の あることが予想された。そこで, 理学電機(株)製の KG3 型蛍光 $\mathrm{X}$ 線分析装置を使用して, 皮膜中に含まれる $\mathrm{SK} \alpha$ 線の波長シフトを測定した。信頼性のあるデータ 一を得るために，測定日を変えて 4 回測定してその平均 值を求めた。な特この場合, $\mathrm{SK} \alpha$ 線の波長のピーク角度 は半值幅から求めた角度 $2 \theta$ とした。測定条件は対陰極

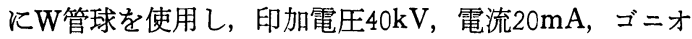
メ一タ一走査角度 $18 \% / 2 \mathrm{~cm} / \mathrm{min}$, 分光結晶 $\mathrm{EDDT}$, 拈 よび検出器にはガスフロー型 PC (1950V) を使用した。

\section{2-6 紫外および可視スペクトル測定}

皮膜を構成する原子の電子状態を測定し，この結果と 皮膜の発色とを関連つける目的で行なった。測定装置は 島津製作所製の MPS-50L 分光光度計を使用した。測定 条件は $\lambda$ SALE : $10 \mathrm{~m} \mu$ (紫外), $4 \mathrm{~m} \mu$ (可視), $\lambda$ SPEED

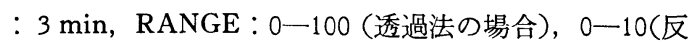
射法の場合), RESPONSE：3, SLIT : 0.05mm（紫 外), $0.03 \mathrm{~mm}$ (可視), PM : auto とした。そして測定 領域は210〜 750m $\mu$ であった。

\section{3. 実験 結 果}

\section{3一1 皮膜の断面色調と微細構造}

ここではさまざまな電解条件で処理した硫酸皮膜の断 面色調を観察したが，その中から代表的なもののみを取 


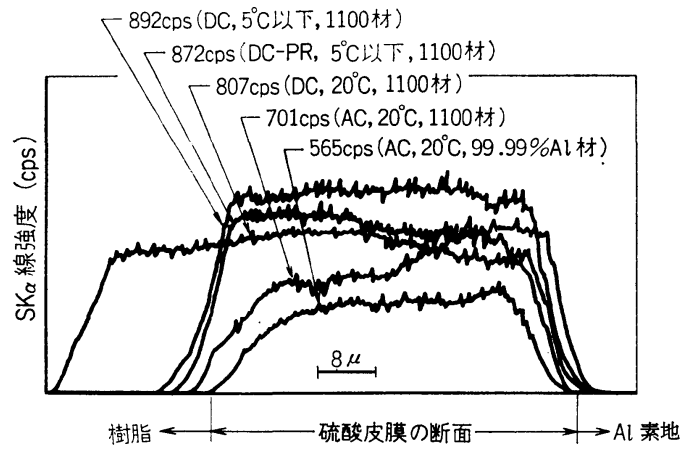

図 2 種々の硫酸皮膜中に拈ける $\mathrm{S}$ 濃度分布

り上げた。1100Al材でDC，20ㄷ処理した皮膜はほぼ無 色であったが，わずかに灰色味を帯びていた。そして $1100 \mathrm{Al}$ 材， DC， $5^{\circ} \mathrm{C}$ 以下で処理した皮膜は淡灰色を呈 していた。また $1100 \mathrm{Al}$ 材, DC-PR，5 ${ }^{\circ} \mathrm{C}$ 以下で処理し た皮膜では，表面が暗カッ色を呈しているが，その断面 は淡灰黄色を帯びていた。同じく $1100 \mathrm{Al}$ 材でAC，20ㄷ 処理した表面が淡灰緑色の皮膜は淡黄カッ色を呈し，か つ99. $99 \% \mathrm{Al}$ 板で $\mathrm{AC} ， 20^{\circ} \mathrm{C}$ 処理した表面があざやかな 黄色を呈する皮膜では，淡乳黄色を帯びているのが観察 された。さらに $1100 \mathrm{Al}$ 材， $5{ }^{\circ} \mathrm{C}$ 以下でプラス成分のみ のパルス波形で処理した，暗灰カッ色の表面色調を有す る皮膜については，暗灰色の断面色調を有するのが認め られた。以上の結果から混酸皮膜では表面色調と断面色 調が異なるけれども，硫酸皮膜では表面色調と断面色調 とがほぼ一致した傾向の色を呈することが認められた。 $1100 \mathrm{Al}$ 材と99.99\% Al 材による差は，99.99\%Al 材では 皮膜の断面色調が全域にわたり均一であったが, $1100 \mathrm{Al}$ 材では99. 99\% Al 材に比べて多少にごった色となって拈 り，しかも観察する場所によっては色の異なる層が見出 される傾向も多く，かつ皮膜中に空気アワ状のものが観 察された。一方，皮膜を加熱してその脱色前後の断面色 調を比較してみると，たとえば $99.99 \% \mathrm{Al}$ 材，AC，20 ${ }^{\circ} \mathrm{C}$ 処理したあざやかな黄色皮膜では，その表面色調の 脱色が顕著であるにもかかわらず，断面色調はそれほど 顕著な差は見出されなかった。偏光顕微鏡による微細構 造の観察の結果は, 交流波形による皮膜では1100, 99.99 $\% \mathrm{Al}$ 材とも異方性が認められ，99.99\% Al材のほうが顕 著であった。そして，1100 Al 材では部分的に内層が極 端に異方性を示すもの，拉よび断面が5〜6 層になりわ ずかに異方性を示すものも見出された。また， $99.99 \%$ $\mathrm{Al}$ 材で処理した皮膜にも2〜3層になっていて,はっきり した異方性を示した。なお, $1100 \mathrm{Al}$ 材で, DC, DC-PR, プラス成分のみののパルス波形で処理した皮膜はほとんど 複屈折性を示さず，皮膜の厚サがとくに厚い皮膜とバー

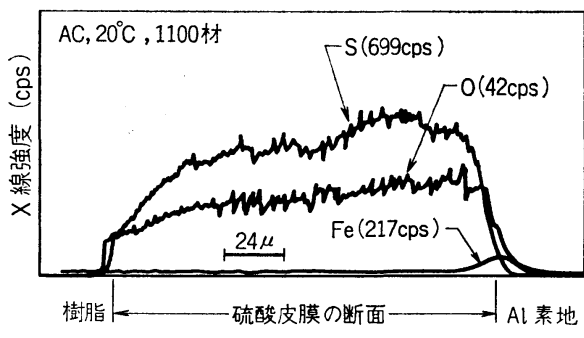

図 3 硫酸皮膜 (AC) 中に打ける諸元素の分布

ニングを起こした部分からは表面層(外層)ほど異方性を 示すものも見出された。

\section{3-2 加熱による脱色試験}

この試験に供した皮膜は, DC， AC， DC-PR および プラス成分のみのパルス波形で処理した皮膜である。試 験の結果, DC, $1100 \mathrm{Al}$ 材で $20^{\circ} \mathrm{C}$ および ${ }^{\circ} \mathrm{C}$ 以下で処 理した皮膜は，温度の上昇に伴ってわずかずつ脱色して いさ，約 $1100^{\circ} \mathrm{C}$ で白色となった。一方，1100Al 材で $\mathrm{AC}$ 処理した皮膜では, $400^{\circ} \mathrm{C} \sim 500^{\circ} \mathrm{C}$ の間で黄色味が 徐々にあせていき，さらに温度を上げると脱色し約 1100 ${ }^{\circ} \mathrm{C}$ で白色皮膜となった。また，99.99\% Al 材の $\mathrm{AC}$ 処 理したあざやかな黄色皮膜は, $1100 \mathrm{Al}$ と同様 $400^{\circ} \mathrm{C} \sim 5$ $00^{\circ} \mathrm{C}$ の間で黄色味はほとんど脱色してしまった。そし て, 約 $1100^{\circ} \mathrm{C}$ 付近で完全に白色となった。1100Al材, D C-PR, $5{ }^{\circ} \mathrm{C}$ 以下で処理 した暗カッ色の皮膜は，400 ${ }^{\circ} \mathrm{C} \sim 500^{\circ} \mathrm{C}$ で AC 皮膜と同様急速にカッ色味が消方， その後はDC 処理による皮膜と同様, 徐々に灰色味があ せていき, $1100^{\circ} \mathrm{C}$ 付近で白色皮膜となった。プラス成 分のみのパルス波形による暗灰カッ色の皮膜の脱色は, ほぼ DC 処理の皮膜と同じような脱色過程を示した。

\section{3-3 皮膜の断面中における Fe， S，O の濃度および 分布}

皮膜断面のX線マイクロアナライザーによる測定は, おのおのの皮膜に 対して加熱前の場合と，500，700， $1000^{\circ} \mathrm{C}$ でそれぞれ加熱後の試料について実施した。 $1100 \mathrm{Al}$ 材, DC, $20^{\circ} \mathrm{C}$ 処理の皮膜断面からは, 図 2 に 示したように陰イオンとして存在する $\mathrm{S}$ の不均一な分布 が認められ，皮膜の表面側ほど濃度が低くなっている。 そして，加熱前後に拈けるSの濃度分布を比較したとこ ろ，当初予想したよらな濃度分布の低下は認められず, ほとんど加熱前後に差は見出せなかった。なお，この試 料に拈けるOの分布状態は，Sの分布と類似であって表 面層ほど濃度の低くなった不均一な分布であった。しか し, $700^{\circ} \mathrm{C}$ 加熱後のOの濃度分布にのみ, $\mathrm{S}$ の分布とは 逆の現象すなわち, 表面層ほど濃度分布の高くなった結 果が得られた。鉄の分布はランダムな分布であった。 


\begin{tabular}{|c|c|c|c|c|c|}
\hline 角 度 & \multicolumn{5}{|c|}{$2 \theta$} \\
\hline 試 料 & 75.10 & 75.15 & 75.2 & 75.25 & 75.3 .7 \\
\hline $\mathrm{CaSO}_{4} \cdot 2 \mathrm{H}_{2} \mathrm{O}$ & & & 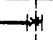 & & \\
\hline $\mathrm{FeSO}_{4} \cdot 7 \mathrm{H}_{2} \mathrm{O}$ & & & & & \\
\hline $\mathrm{NH}_{2} \mathrm{SO}_{3} \mathrm{H}$ & & & & & \\
\hline 硫酸皮膜DC $\quad\left(\begin{array}{c}1100 \\
20^{\circ} \mathrm{C}\end{array}\right)$ & & & & & \\
\hline 硫酸皮膜DC $\left(\begin{array}{c}1100 \\
\left.5^{\circ} \mathrm{C} \text { 以下 }\right)\end{array}\right)$ & & & & & \\
\hline 硫酸皮膜PR $\left(\begin{array}{c}(1100 \\
5^{\circ} \mathrm{C} \text { 以下 }\end{array}\right)$ & & & & & \\
\hline 硫酸皮膜AC $\left(\begin{array}{l}1100 \\
20^{\circ} \mathrm{C}\end{array}\right)$ & & & & & \\
\hline 硫酸皮膜AC $\left(\begin{array}{c}99.99 \% \mathrm{Al} \\
20 \mathrm{Cl}\end{array}\right)$ & & & & & \\
\hline イオウ粉末(試薬) & & & & & \\
\hline
\end{tabular}

图 4 蛍光 $\mathrm{X}$ 線による $\mathrm{SK} \alpha$ 線の波長シフト

$1100 \mathrm{Al}$ 材, $\mathrm{DC}, 5^{\circ} \mathrm{C}$ 以下で処理した皮膜では，加熱 前後のすべての試料について な分布であった。 $\mathrm{Fe}$ の分布は $20^{\circ} \mathrm{C}$ の場合と同様にラン ダムな分布であって， $\mathrm{Fe}$ の濃度分布がとくに高い所で は (1000cps 以上) この影響を受けて S の濃度が逆に低 くなっているところも観察された。AC，1100 Al 材で処 理した皮膜では，S，Oの分布は図2に見られるように 表面層側での濃度の低くなった山形の不均一な分布であ った。そして，加熱前後での $\mathrm{S}$ の濃度には汪とんど差は 見出されなかった。な报，交流波形による皮膜中には陰 イオンとしての S のほかにイオウを含むことが考えら れ，このイオウが比較的低温 $\left(440 \sim 450^{\circ} \mathrm{C}\right)^{97}$ で抜ける ことが予想されたが，この測定の結果からは，明確な差 は見出せなかった。さらにこの皮膜で注目すべき点は，

図 3 に示したよらに， $\mathrm{Fe}$ が皮膜とアルミニウム素材 の境界付近に数 $\mu$ にたたって分布している現象が認めら れた。さらに $99.99 \% \mathrm{Al}$ 材， $\mathrm{AC}$ 処理した黄色皮膜から は, $\mathrm{S}$ の濃度分布が $1100 \mathrm{Al}$ 材と同様に山形の不均一分 布を示し，かつ加熱前後に打汸るSの濃度分布には顕著 な差は見出せなかった。酸素の濃度分布は S と類似の分 布を示し， $\mathrm{Fe}$ の濃度分布は $99.99 \% \mathrm{Al}$ 材を用いたため 認められなかった。1100Al 材， $5{ }^{\circ} \mathrm{C}$ 以下，DC-PR 波 形による皮膜中での $\mathrm{S}$ の分布は，上記皮膜とはまったく 逆の現象が認められ、皮膜の表面層ほど濃度の高くなっ た不均一な分布を認めた。一方，酸素は皮膜断面の全域に わたって均一な分布を示し， Fe はランダムな分布とし て認められた。以上の 5 種類の皮膜について，その分布 する諸元素の濃度をX線強度から比較すると, 酸素の場 合，皮膜の種類による濃度差はほとんどなかったけれど も， $\mathrm{S}$ の濃度は電解条件による差が認められている。 $\mathrm{Fe}$ はS と同様, 皮膜によっては多少ばらついた濃度差が認 められるが，アルミニウム素材中の $\mathrm{Fe}$ がランダムに分 布していることから,この差は1100Al材，AC 波形による

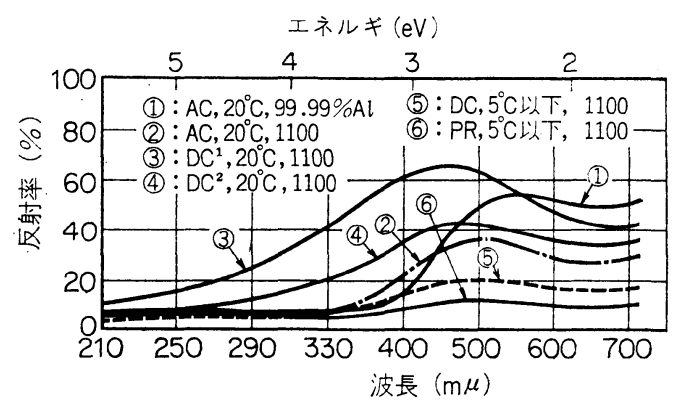

図 5 種々の波形による硫酸皮膜の紫外・可視吸収 スペクトル（反射法）

皮膜を除けば，素材によるバラッキと考えた㴽うが妥当 であろう。

\section{3-4 皮膜中の SK $\alpha$ 線のケミカルシフト}

硫酸皮膜中に存在するイオウは, 直流電解のような酸 化反応では主として $\mathrm{SO}_{4}{ }^{2-}$ イオンのような陰イオンの形 で存在していることはすでによく知られている。しかし 交流のように電解波形にマイナス成分が入ってくると， 還元反応が起こりイオウあるいは硫化物のような配位数 の異なるSが析出することが予想された。それゆ光，蛍 光X線により $\mathrm{SK} \alpha$ 線のピーク角度 $(2 \theta)$ のケミカルシ フトを測定したところ，图4亿示したような結果が得ら れ， $\mathrm{AC}$ 波形で処理した皮膜中の $\mathrm{S}$ に明らかな差が認め られた。各種皮膜についてのSK $\alpha$ 線のピーク角度 (2 $\theta$ ) の平均値は $\mathrm{DC}, 20^{\circ} \mathrm{C}$ の皮膜では $75.1913^{\circ}, \mathrm{DC}, 5^{\circ} \mathrm{C}$ 以下の皮膜では $75.1900^{\circ}$ ，また, DC-PR, $5^{\circ} \mathrm{C}$ 以下の 皮膜では $75.1883^{\circ}$ となった。一方， AC 波形に上る皮膜 では1100Al 材の場合75.2028となり，上記皮膜に比べて 高角度側へシフトしており, $99.99 \% \mathrm{Al}$ 材では $75.2141^{\circ}$ となり，さらに高角度側ヘシフトしている。一方，硫酸 塩のような試薬中の $\mathrm{S}$ は75.1967〜 75.20の間の值を取 っていて, 硫酸皮膜のうちの DC と DC-PR 波形で処理 した皮膜中の S とほぼ近似した值を取っている。試薬の イオウ粉末に至っては $75.2441^{\circ}$ とかなり高角度側ヘシフ 卜していて，99.99\% Al 材， AC 波形で処理したあざ やかな黄色を呈した皮膜とかなり近似した值となってい る。

\section{3-5 紫外可視スペクトル}

この測定は皮膜の電子配置を調べるために行なった が，その中から代表例を図 5 に揭げた。これによると， 反射法による皮膜の紫外可視スペクトルは皮膜の電子配 置を的確に表わすシャープな吸収は見出されず，ブロ一 ドなスペクトルが得られたにすぎなかった。すなわち， DC 波形で処理した皮膜のスペクトルでは 460〜 480 $\mu$ 付近に幅広い吸収スペクトルが認められた。そして表面 色調が無色 $\rightarrow$ 灰色 $\rightarrow$ 暗カッ色と変化するにつれて，スペ クトルは長波長側へずれる傾向を示し，かつ反射率も低 
(1)：パルス, $20^{\circ} \mathrm{C}, 99.99 \% \mathrm{Al}$ 材

(2): DC, $20^{\circ} \mathrm{C}, 99.99 \% \mathrm{Al}$ 材

(3): DC, $5{ }^{\circ} \mathrm{C}, 99.99 \% \mathrm{AL}$ 材

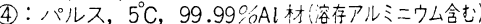

(5): パルス, $20^{\circ} \mathrm{C}, 1100 \mathrm{Al}$ 材(1)

(6): パルス, 50, $99.99 \% \mathrm{Al}$ 材

(7): パルス, 20ㄷ, 1100AL 材 (2)

(8): パルス, 5. ${ }^{\circ} \mathrm{C}, 1100 \mathrm{Al}$ 材(2)

(9): パルス-PR, 50 C, 99.99\%Al 材

(10): DC-PR, $5^{\circ} \mathrm{C}, 99.99 \% \mathrm{Al}$ 材

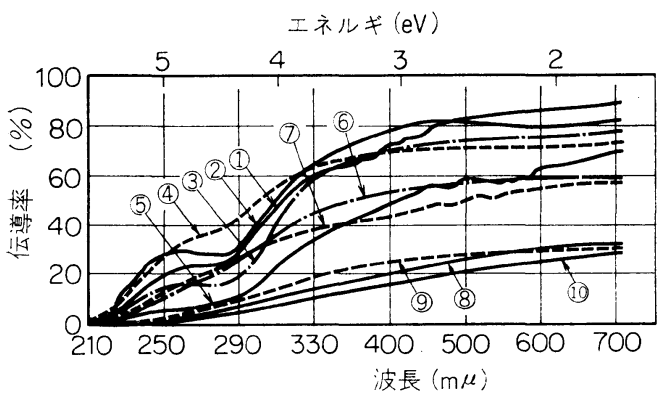

図 6 種々の電解波形による硫酸皮膜の 紫外・可視吸収スペクトル（透過法）

下している。AC 波形で処理した黄色皮膜については， 他の皮膜に比べてさらに著しく長波長側へずれる傾向に あり，皮膜の電子構造が他の皮膜と異なっていることが 考兄られた。さらに DC-PR 波形, $1100 \mathrm{Al}$ 材を用いて $5^{\circ} \mathrm{C}$ 以下, $10^{\circ} \mathrm{C}, 20^{\circ} \mathrm{C}$ の温度でそれぞれ皮膜の厚サを $1 \mu \sim 50 \mu$ の間で5〜6段階に分けてその表面のスペクト ルを測定した。そして, 皮膜の発色が皮膜を構成する元 素の電子軌道エネルギ準位間の電子の励起による吸収帯 として示されるかどうかについても検討した。この結果 皮膜の厚サが数 $\mu$ 程度では無色であり,だんだん厚くな るとカッ色を経て黒カッ色となり，その吸収スペクトル も430から500 m $\mu$ まで長波長側へずれる傾向があった。 一方, $99.99 \% \mathrm{Al}$ 材を用いて DC-PR 波形, $5{ }^{\circ} \mathrm{C}$ 以下, $10^{\circ} \mathrm{C}, 20^{\circ} \mathrm{C}$ の条件で $1100 \mathrm{Al}$ 材と同様に 皮膜厚兵学 の表面色調（皮膜が厚くなってもカッ色を呈している） そついてのスペクトルを測定した。この結果, $99.99 \% \mathrm{Al}$ 材によるその吸収スペクトルはほぼ455から485m $\mu$ まで 長波長へずれたが， $1100 \mathrm{Al}$ 材とは逆に色が濃くなるほ ど反射率の增加が認められた。そして，この場合は皮膜 の視感による「ッヤ」がみられた。DC-PR 波形, 1100 $\mathrm{Al}$ 材, $20^{\circ} \mathrm{C}$ 処理した皮膜厚施 $1 \mu$ の干渉色を呈した 皮膜のスペクトルは，波状のスペクトルとなった。ま た, 膜厚が $4 \mu$ で息とんど無色の皮膜からは, 紫外領域 の $287 \mathrm{~m} \mu$ 付近に吸収が認められ，15 $\mu$ の皮膜では $278 \mathrm{~m} \mu$ 付近に同様の吸収が認められた。そして皮膜厚サが $29 \mu$ になると $287 \mathrm{~m} \mu$ と $310 \mathrm{~m} \mu$ 付近の 2 個所に吸収が現わ れ， $48 \mu$ の皮膜では $286 \mathrm{~m} \mu$ 付近に吸収が認められた。 以上のように, 反射法では明確なスペクトルが得られ ず, したがって, 皮膜のエネルギ準位間の電子の励起に よる吸収帯と表面色調の関係はつかめなかった。このよ
らなことからさらに透過法により紫外可視スペクトルを 測定した。この結果図6に示したように，かなりはっき りした吸収スペクトルの得られる皮膜もあった。スペク トルから求められる顕著な吸収は, 紫外領域では $280 \mathrm{~m} \mu$ を中心とした左右の約254〜320m $\mu$ に扤よぶ幅広い吸収 である。そして，この吸収を含む皮膜は $\mathrm{DC}, 20^{\circ} \mathrm{C}$ と $5{ }^{\circ} \mathrm{C}$ 以下， $99.99 \% \mathrm{Al}$ 材による 2 種類の皮膜, プラス 成分のみのパルス波形で $20^{\circ} \mathrm{C} ， 99.99 \% \mathrm{Al}$ 材と $1100 \mathrm{Al}$ 材で処理した 2 種類の皮膜, 扣よび同様なパルス波形で $5{ }^{\circ} \mathrm{C}$ 以下, $99.99 \% \mathrm{Al}$ 材, 溶存アルミニウム $20 \mathrm{~g} / l$ を 含む液で処理した合計 5 種類の皮膜に顕著であった。ま た可視領域で吸収の認められた皮膜は，プラス成分のみ のパルス波形で $20^{\circ} \mathrm{C}, 1100 \mathrm{Al}$ 材で処理した暗カッ色皮

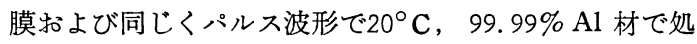
理した暗カッ色とカッ色の 2 種類の皮膜であった。以上 の結果から, 吸収スペクトルの認められた皮膜と認めら れない皮膜の表面色調に対する吸収スペクトルの効果 を比較検討したが，はっきりした結論は見出せなかっ た。

なお，吸収スペクトルの認められた皮膜は，認められ ない皮膜に比べて透過度が高くなる傾向にあった。

\section{4. 考察}

以上の実験結果にもとづき，主として結晶化学的推論 を加觉ながら，皮膜の発色機構につき述べてみたい。硫 酸皮膜の発色については，今のところイオウおよびアル ミニウム素材中の遷移金属のような微量金属を中心とし た不純物元素が考兄られている。しかし，決定的な発色 機構は解明されていない。本実駼結果にしたがって順に 考察を加えると，まず DC 波形で低温電解生成した皮膜 は従来から言われているように灰色系の発色を呈した が，液温度が高くなるにしたがって，色はしだいに淡く なった。ここで注目すべきことは，室温付近の温度で処 理した皮膜は半透明であるが，良く観察するとかなりに ごった淡い灰色味を帯びていることである。一方，AC 波形では黄色系の発色皮膜が得られ, 蛍光X線によるケ ミカルシフトから皮膜中には硫酸イオンの他にイオウが 含まれていることが推定された。そこで，DC-PR 波形 を用いて酸化還元をコントロールすればイオウの析出量 もコントロールできるるのと考えた。さらにこの波形を 用いて低温電解すれば，イオウによる黄色に灰色系の色 調が加重されてカッ色系の皮膜が得られると予想した。 このような考觉のもとに試料を作成したところ，主とし てカッ色から暗カッ色に至る色調が得られた。そして, こ の皮膜を加熱処理して，その脱色の様子を調べたところ $400 \sim 500^{\circ} \mathrm{C}$ の間で黄色味が拔け，その後は灰色味を帯 びた皮膜となった。したがって，DC-PR 波形でもAC 


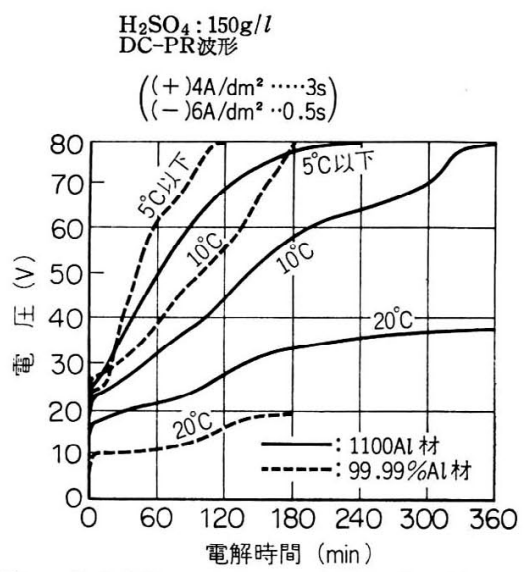

図 7 DC-PR 波形に上る硫酸皮膜の V-t 曲線 (プラス成分のみ)

皮膜と同様皮膜中にイオウが存在するのであらら。しか し, $\mathrm{SK} \alpha$ 線のケミカルシフトからは DC-PR波形で処理 した皮膜の波長シフトは認められなかった。これは,こ の波形が $\mathrm{AC}$ 波形ほどマイナス成分を含まないためイオ ウの析出量は少なく, 硫酸イオンの占める割合が優先し ていると考兄られる。硫酸皮膜の黄色がイオウの析出に よる発色とすると，X線マイクロアナライザーの測定結 果からはつぎのようなことが考察できる。発色皮膜を高 温に加熱して黄色味の消光た試料と加熱前の試料との間 には，皮膜の断面中に存在する $\mathrm{S}$ の量にはほとんど差が 認められないことから, 黄色に拉よぼすイオウはごく微 量でよいことになる。一方, 低温処理による灰色系の色調 は，加熱処理により徐々に消光ていき約 $1100^{\circ} \mathrm{C}$ 以上の 温度にならないと完全に脱色しない。このことから低温 電解による灰色系の発色原因のすべてが，アルミニウム 素材中に含まれている不純物元素とすると, $1100^{\circ} \mathrm{C}$ 付近 で不純物元素が消失あるいは何らかの変化が生じたこと になる。しかしX線マイクロアナライザーの結果では， たと壳ば不純物としてもっとも多く含まれている $\mathrm{Fe}$ の

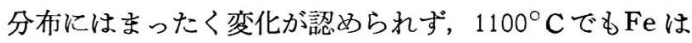
ランダムに分布している。このよらな理由からのみなら ず, この発色原因を他に求めることが必要であろう。そ こで, 灰色系の発色原因をつきつめると, 低温電解すると いらことは図７亿示したよらに，電圧が高くしか子その 上昇が著しくなることに注目するならば，発色の原因は 皮膜の構造的な問題であるように思われる。そしてDC, $20^{\circ} \mathrm{C}$ で処理した皮膜もわずか火 発色していることを考 虑し，低温にすればするほど皮膜の色が黒味を増しかつ 電圧が高い事実から厳密には皮膜の生成点に抢汀る熱エ ネルギの差が構造上の差として発色に影響をおよぼすで あろら。しかも，非晶質の皮膜はある一つの温度で疑固 するのではなく，温度を下げるほど徐々に固くなること
液組成：シュウ酸 $30 \mathrm{~g} / \mathrm{l}$

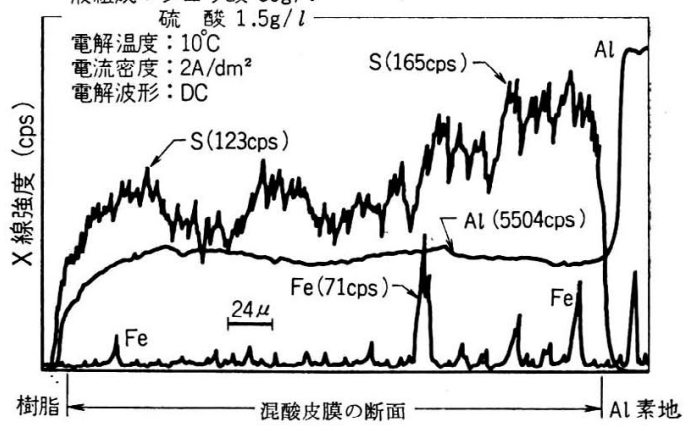

図 8 混酸皮膜中に拈ける諸元素の濃度分布

から, 皮膜の結合力の増減といった構造上の差も当然発 色に影響してくると考えられる。これらのことから，皮 膜の灰色系発色の扣もな原因としては構造上の欠陥が取 り上げられる。この場合，低温処理した皮膜のほうが， 皮膜の生成点での熱的影響等によって不規則構造になっ ていると推定される。一般に結晶構造を有する物質で は，まったく欠陥を持たないものは汪とんど存在しな いし，規則構造を有するものより不規則構造を有するも ののほらが点欠陷9を多く含みやすい。このようなこと から皮膜は, $\mathrm{Al}$ が配位数 4 と6を取るけれども，安定な 三次元構造を作りにくく，非晶質になっていると思われ る。したがって発色皮膜の加熱による脱色過程に関して も,構造的な解釈をすると,初めは欠陥の多い不規則構造 を有する無定形アルミナが，加熱によってしだいに結晶 化が進行し前よりも欠陷の少ない $\gamma-\mathrm{Al}_{2} \mathrm{O}_{3}$ に転移する。 この段階ではまだうすい灰色味を帯びている。そしてさ らに加熱すると, 最終的には約 $1100^{\circ} \mathrm{C}$ 以上で構造的欠 陥のきわぬて少ない安定した $\alpha-\mathrm{Al}_{2} \mathrm{O}_{3}$ 飞転移して，完 全に脱色した白色皮膜になったと想像される。この間, 温度の上昇に伴って皮膜の脱色が徐々に起こっているこ とと, 結晶化の進行していく現象とがょく一致してい

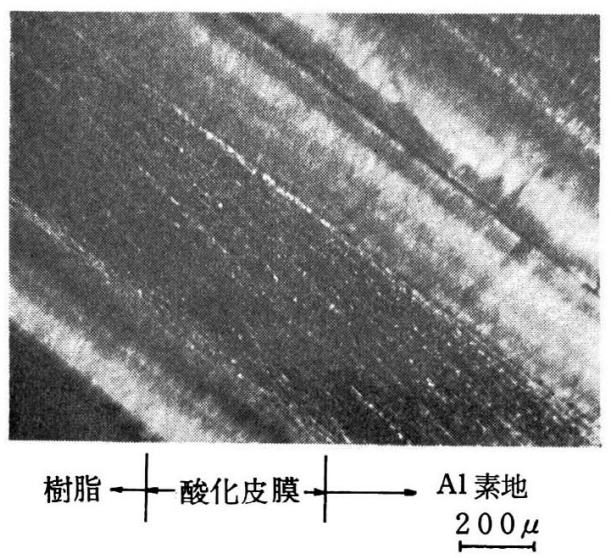

写真 1 混酸皮膜 の 断面 
る。このように考えていくと, 発色皮膜中には点欠陥が 存在することから, 当然電子のトラップも可能であろ ら。この場合, キャリャーに対するトラップを形成するる のとしては, 皮膜中の過㮃な $\mathrm{Al}$ また 0 欠陥が考えら れる。しかし, 低温処理したグレー系の発色原因は, 主 として電子の寄与といらょりむしろ結晶構造上の問題で あって，それには皮膜中にショットキー欠陥のような点 欠陷を多く含むような三次元構造，すなわち悪酸化物の ようなものの存在が予想される。

さてここで, 陽極酸化時に沶いて電子を運ぶものが $\mathrm{SO}_{4}{ }^{2-}$ イオン10) であるとするならば，写真 1 および図 8 に示した結果が参考になる。すなわち写真 1 はシュウ酸 と硫酸の混酸溶液中で処理した, きわめて厚い皮膜の断 面を撮影したものであって，その表面色調は実際は暗青 色である。そして, この断面は青色, 灰色拉よび白色の濃 淡からなる5層を観察することがでさる。そこでこの皮 膜の断面につき, X線マイクロアナライザーを用いて $\mathrm{S}$, $\mathrm{Al}, \mathrm{Fe}$ の濃度分布を測定したのが図 8 である。測定の 結果については, Fe がランダムな分布であり， $\mathrm{Al}$ はほ ぼ均一な濃度分布を示したが， Sはその濃度分布を大き く分けると5つの山からなっていて，この分布と写真 1 飞示した色調からみた断面層とが一致している。このこ

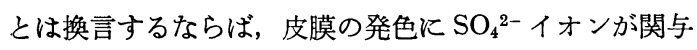
しているといらことである。しかも, $\mathrm{SO}_{4}{ }^{2-}$ イオンが電 子を運ぶとすると, 色調面から観察される断面層には, $\mathrm{SO}_{4}{ }^{2-}$ イオンの濃度に比例してトラップされた電子の濃 度があると考えることができる。このように, 皮膜の発 色がアルミナの構造的欠陷に基ついた電子との相互作用 からなることが判明したので, 意識的にこれらの発色因 子をらまくコントロールしてやれば，さらに容易でしか も顕著な発色皮膜が得られるものと考えた。そこで, 図 1 に示したようなパルス波形とパルス-PR波形のような 特殊な電解波形を用いて発色の有無を検討した。この結 果, パルス波形による発色は DC-PR 波形によるカッ 色, 暗カッ色とは外観的に多少異なっているけれどる, 暗カッ色から暗灰色に至るさまざまな色調が観察され た。そして得られた発色皮膜の色調は DC, DC-PR, $\mathrm{DC} \cdot \mathrm{AC}$ 併用およびこれらの $\mathrm{PR}$ 波形で処理した発色よ りも濃色になっていた。パルス-PR波形で処理した皮膜 はイオウの影響を受けたのか，パルス波形による発色皮 膜よりも色は淡いがカッ色味はかえって強かった。この ようにもっとも濃色皮膜が得られたのがパルス波形であ ったことから, 負電流を流さなくても, 正電流のみでし か子常温でも十分に発色皮膜が得られることを認めた。 以上の事実から,ささら発色の原因を追求してみると, パルス波形ではごく一般的な $2 \mathrm{~A} / \mathrm{dm}^{2}$ 程度で酸化皮膜 を生成せしめながら, 瞬間的に $8 \mathrm{~A} / \mathrm{dm}^{2}$ といった高電
流密度で皮膜に電気的な衝撃を与えることによって発色 したものと思われた。ここで, 電気的衝撃が皮膜におよ ぼす効果を考えてみると, 皮膜中に電子が注入されるこ とのほかに, 結晶構造面からみてもより多くの久陥が存 在してもよいはずである。な抏, 現時点では皮膜を構成 するものは, 無定形の $\mathrm{Al}_{2} \mathrm{O}_{3}$ と考光られている。しか し，パルス波形を用いて短時間に高電圧をかけた場合， より多くの点欠陥が生じて三次元構造を乱したことによ る発色とすると, $\mathrm{Al}$ が酸化されて $\mathrm{Al}_{2} \mathrm{O}_{3}$ の状態になる前 の過程で酸化反応が止まったような低級酸化物 $\left(\mathrm{Al}_{2} \mathrm{O}\right.$, A10）の存在が考えられる。な拈, この亜酸化物の存在 は, 熱力学的にはすでに知られている11。このようなこ とから, 電子線回折法により皮膜の分析を行なった結 果, ASTM カードに一致しない回折環が認められた。 しかし, $\mathrm{Al}$ の亜酸化物かどうかの同定については現在 検討中であり, 今後さらに追求を要する課題である。そ して,さらに DC 波形とパルス波形で処理した皮膜の ESR スペクトルを測定したところ，シュウ 酸皮膜に見 られるよらな強い共鳴吸収は認められなかった。したが って硫酸皮膜では, 電子の発色に括よぼす影響はシュウ 酸皮膜ほど著しくないことからす, $\mathrm{Al}$ の亜酸化物の存 在による構造上の欠陥のほらが寄与していると思われ た。さらに種々の電解波形で処理した発色皮膜にX線を 照射して, 照射前後の紫外可視吸収スペクトルの変化を 測定したところ, 照射後のスペクトルに変化が認められ た。この場合, X線を照射した皮膜はカッ色味を増し色 が濃くなる傾向にあった。そこで, さらにこれらの皮膜 に対して, 同様にX線照射前後の ESR スペクトルの変 化を測定した結果, 照射後の皮膜から共鳴吸収が認めら れた。したがってこのことからも, 皮膜の電子構造を变 化させれば，その発色状態も变わることを認めた。とく に DC, $20^{\circ} \mathrm{C}$ で処理した無色の皮膜にX線を照射した ところ, カッ色系の発色を呈したことから, カッ色系の発 色は格子欠陥に相当する構造の電子構造によることが認 められ，灰色系の発色原因とは区別することができた。 な拈, DC-PR，パルス-PR 波形で処理した皮膜の X 線照 射前後の ESRスペクトルからは, いずれもシュウ酸皮膜 と類似の強い共鳴吸収が得られた。これは皮膜中に存在 するイオウによる現象と考えられた。

\section{5. 結 論}

この研究では, 硫酸単独液を用いて皮膜の発色に関す る種々の試みを行なった。以下にこの結果をまとめて結 論とした。

（1）硫酸のような無機酸のみでもカッ色，暗カッ色お よび暗灰色のよらな電解発色皮膜を得ることができた。

(2) $1100 \mathrm{Al}$ 材を用いて交流高電流密度で化成した皮 
膜中からは, $\mathrm{Fe}$ がアルミニウム素地と皮膜との境界付 近に集中した分布を取るのが認められた。しかし， $\mathrm{Fe}$ ? と発色々の関係については明らかではなかった。

(3) 負の成分を含む電解波形で処理した皮膜中にはイ オウが存在し，かつこれが発色に影響を拈よぼしている と思われた。

(4) DC 波形やパルス波形のよらに正成分のみの電解 波形による死色系の発色原因は，不純物元素の他に低級 酸化物などの存在による皮膜の構造上の問題であるよう に推察された。さらに，X線のような電磁波を照射する と無色の皮膜がカッ色を呈することと， ESR の測定結 果とを合わせて考えれば, 皮膜の欠陥構造と電子構造と が発色に寄与することも推定できた。

終わりに本研究の実施にあたり，なにかとご協力いた だいた東京工業大学・工業材料研究所の安田栄一助手な らびに烟野東一助手，そして ESR スペクトルの測定に さいしご指導たまわった都立大学助教授の馬場宣良博士 々電子線回折の分析に対してご支援くだされた無機材質 研究所の山口成人博士に深く感謝するしだいである。

$$
\text { (1973-7-3 受理) }
$$

（昭和 47 年 11 月抢よび昭和 48 年 5 月，本協会第46回㧍よ び第47回学術講演大会にて発表)

\section{文献}

1) 高橋俊郎, 長野年宏, 和田健二, 鈴木康史, 田賀井 秀夫，木村脩七，本誌，23，700（1972）

2) T. Muramaki, N. Baba, S. Tajima, Extended Abstr. 4 th. Internl. Congr. Metallic Corrosion, 177 (1969)

3) 吉野隆子, 馬場宣良, 本誌, 24, 258 (1973)

4) 中山孝廉, アルミニウムの表面処理, p.154（日刊 工業新聞社)

5）小泉宗栄, 生田良三, 上田重朋, 本誌, 24, 26 (1673)

6) 百瀬孝昭, 馬場宣良, 田島栄, 日本化学会第28回春 季年会講演予稿集, p.661 (1973)

7 ) 田島栄, 佐藤不二生, 馬場宣良, 福島敏郎, 電気化 学, 27, 647 (1959)

8) 莚正勝, アルミニウム表面処理研究調査報告, 第69 号, $4 \sim 5$ (1973)

9) ショョンウルフ, 物質の構造, p.98〜113（1972, 岩 波書店)

10）馬場宣良，本誌，24，34（1973）

11) K. Prabriputaloong and M. R. Piggott, Journal of the American Ceramic Society, April, 179, (1973)

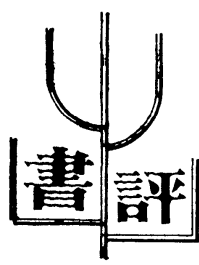

\section{日本材料科学会, 材料科学シリーズ}

\section{金 属 複 合 材 料}

金属を主成分とした複合材料の学問はきわめて新しい 分野であり，その急速な発展はこの 5〜6年間のことで ある。そこで, 工場でも学校でもこの方面を少し調べた いとする人がかなり多いが，手軽でよくまとまった本が ない。これに対して本著の編者三浦教授の研究室は全員 こぞって複合材料の研究をして扣られ，各人相互に十分 討論が行なえる環境で，そこから生みだされたのがこれ である。執筆者は研究室の若い研究者達であるが，この ような新規の分野の勉強は若い者でなければ行なえな い。よく整理され，らまくまとめられている。まず複合 材料発展の基礎となる 微視力学, 界面問題などを扱っ て, 強化機構を明らかにすることに努力されていて, 読 者の勉強に好都合であり, 交献も多数紹介してある。材
A 5 判, 174ページ, 共立出版秼, 定価 1,400円

\section{三 浦 維 四 編}

料の組織構造を微視力学の観点からコントロールし,さ らに複合する材料相互間の界面問題の応用を考えて扱兄 るように整理されてある。

ついで, 複合材料各論に打よんで, 粒子分散強化合 金, 繊維強化合金を述べている。粒子分散の強化の問 題, 強化機構について説明し, 複合材料の作成方法にお よんでいる。さらに，最近ほうぼうでとり上げられてい る合金の組織制御による複合合金も詳細に述べられてい る。

粒子, 繊維, 䇴などへのメッキ, ニーティングなどの 表面技術を駆使した複合材料も考えられている折から， 金属表面技術にたずさわられる諸兄に本書を紹介するこ とは有意義と考えたしだいである。

（葉山房夫） 